\title{
The Revitalization of Makassar Urban Drainage System Based on Eco Drainage Retention Pond
}

\author{
Riswal Karamma ${ }^{1, a, *}$, Rita Tahir Lopa ${ }^{1, b}$ Mukhsan Putra Hatta ${ }^{1, c}$ \\ ${ }^{1}$ Civil Engineering Department, Hasanuddin University, Makassar Indonesia \\ *,a riswalchiwal@gmail.com (Corresponding Author)
}

\begin{abstract}
One of the causes of flooding in Makassar City is the management of the water system that is not optimal. It is necessary to arrange a drainage system to overcome flooding in Makassar City. In this study the topography on Catchment area analysis, analysis of hydrology and hydraulics analysis. Modeling the distribution of flood performed using HEC-RAS applications. This research was conducted in the Tallo watershed which consists of the Upper Tallo sub-watershed and the Mangalarang sub-watershed. The results of the analysis of flood discharge in the Tallo Hilir sub-watershed are $523.76 \mathrm{~m}^{3} / \mathrm{s}$ and in the Mangalarang sub-watershed are $886.82 \mathrm{~m}^{3} / \mathrm{s}$. The flood overflow of the Tallo River spread over $6.48 \mathrm{~km}^{2}$ of Manggala District, $0.31 \mathrm{~km}^{2}$ of Rappocini District, $4.24 \mathrm{~km}^{2}$ of Panakukang District, $3.37 \mathrm{~km}^{2}$ of Tallo District, $11.59 \mathrm{~km}^{2}$ of Tamalanrea District and $0.01 \mathrm{~km}^{2}$ of Biringkanaya District. The total area of flood distribution is $26 \mathrm{~km}^{2}$. The solution to overcome the flooding of the Tallo River with an environmentally sound drainage system, it is necessary to plan the construction of a retention pond in Tamalanrea District, with a normal total storage volume of 2.48 million $\mathrm{m}^{3}$ and a maximum capacity of 5.31 million $\mathrm{m}^{3}$. The construction of this retention pond can reduce $17.7 \mathrm{~km}^{2}$ of floodaffected area.
\end{abstract}

Keywords-Flood; Hydrology; Tallo River

\section{Introduction}

One of the main causes of inundation and flooding in urban areas is the occurrence of changes in land use patterns that are not followed by the arrangement of the drainage system [1]. The development of the area is no longer in accordance with spatial planning or the concept of sustainable development resulting in changes in land use patterns so that low areas and riverbanks become residential areas [2].

Almost every year the flood disaster in Makassar occurs at every arrival of the rainy season [3].
The worst flooding in the last decade in Makassar City occurred in 2019 which submerged 4 sub-districts, namely Panakukang District, Manggala District, and Biringkanaya District as high as $50 \mathrm{~cm}$ to $200 \mathrm{~cm}$. The main cause of the flood was due to the relatively high intensity of rainfall on January 21 and 22, 2020 so that the Tallo and Jeneberang Rivers were unable to accommodate the flood discharge [4]. Floods in Makassar City are not only influenced by the relatively high intensity of rainfall, topographical conditions in the form of a basin, increased flow discharge, changes in land use patterns and sea water tides, are also influenced by the inadequate drainage system, although the city government has programmed and building infrastructure but the problem of flooding is still a serious problem [5]. Ujung Pandang District has not been free from the threat of flooding and inundation, so that drainage arrangements are needed as city infrastructure that is useful for draining excess water in an area [6].

Floods and puddles in a residential area still occur in many cities in Indonesia. Floods or puddles in an area occur when the drainage system is unable to accommodate the flowing discharge. In urban areas, drainage functions to drain parts of the city's administrative area and urban areas from puddles of water, both from local rain and overflowing rivers that pass through the city. River revitalization itself is an effort to restore river functions which include functions as irrigation and ecological functions [7]. River revitalization is a concept to correct the previous concept of river development [8]. The drainage system as an integral part of the water management system, the drainage system revitalization program uses a participatory approach with the aim of changing people's behavior towards the importance of a good drainage system [9]. 


\section{Research Methodology}

\section{A. Data Collection}

The data needed in this study is divided into two types, namely primary data and secondary data. Data collection was carried out by directly observing the Tallo River in several areas to determine the condition and function of the river in that area. This research was conducted in the Tallo River Basin starting from the Nipa - Nipa Regulatory Pool to the Muara or at coordinates $5^{\circ} 10^{\prime} 3.13^{\prime \prime}$ South Latitude and $119^{\circ}$ 31'10.93" East Longitude to $5^{\circ} 6^{\prime} 15.15^{\prime \prime}$ South Latitude and $119^{\circ} 26^{\prime} 56.08^{\prime \prime}$ East Longitude.

\section{B. Data Analysis}

The topographic data used in this study were obtained from the Indonesian Earth Map (RBI) Scale 1:50,000 and DEMNAS data to determine the catchment area that will be used in the 2D HECRAS flood simulation.

\section{Hydrological Analysis}

Rainfall data used were taken from Panakkukang Station, Tamangapa Kassi Station, Senre Station, Sungguminasa Station and Malino Station. The Rainfall data obtained from 1995 to 2019. Calculation of the average rainfall using the algebraic, isohyet and thiesen average methods. It was analyzed by using the Gumbell and Log Person III distribution Methods. Then, a statistical test of the rainfall data and a "Chi Squared and Smirnof-Kolmogorof" distribution test was carried out to determine the most suitable Frequency Distribution Method. The calculation of the planned rainfall intensity is analysis using the Mononobe method. The analysis method of the flood discharge design was calculated using the Nakayasu Synthesis Unit Hydrograph[10]. The stages of the Nakayasu synthetic hydrograph unit are:

Hydrograph peak discharge

$$
Q_{p}=\frac{1}{3,6} \times A \times R_{0} \times \frac{1}{\left(0,3 t_{p}+t_{0,3}\right)}
$$

Lag time

$$
\begin{aligned}
& t_{g}=0,4+0,058 \cdot L \quad(\mathrm{~L}>15 \mathrm{~km}) \\
& t_{g}=0,21 \cdot L^{0,7} \quad(\mathrm{~L}<15 \mathrm{~km})
\end{aligned}
$$

Discharge time

$$
t_{0,3}=\alpha \cdot t_{g}
$$

Peak time

$$
t_{p}=t_{g}+0,8 T_{r}
$$

Where $\mathrm{Q}_{\mathrm{p}}$ is peak discharge $\left(\mathrm{m}^{3} / \mathrm{sec}\right), \mathrm{t}_{\mathrm{g}}$ is the gap time (hour), A is Watershed Area $\left(\mathrm{km}^{2}\right), \mathrm{L}$ is river length $(\mathrm{km})$, $\mathrm{t}_{0,3}$ is discharge time equal to 0,3 peak (jam), $\mathrm{t}_{\mathrm{p}}$ is peak time (hours), $\alpha$ is coefficient with the value ranges from $1.5-2, \mathrm{~T}_{\mathrm{r}}$ is rainfall duration (hours), $\mathrm{R}_{0}$ is rain depth unit (mm). Analysis of the river flood modeling using HEC-RAS application based on river geometry data and planned flood discharge inflow. Outflow modeling is the flood water level elevation for each flood discharge plan. Furthermore, simulation of flood control is carried out.

\section{Alternative Countermeasures}

Alternative countermeasures are carried out if the river's capacity is insufficient. The alternative to overcome this problem can be in the form of revitalizing the drainage system with eco drainage. The application of ecodrain can be done in several ways. Retention methods are divided into two types, namely "offsite retention", for example the creation of ponds or reservoirs and "on site retention", for example retention on building roofs, parks, parking lots, open fields, and yards. The method of "infiltration" is by making artificial recharge in certain areas in the form of infiltration wells, infiltration ditches, infiltration areas, pavements that pass water. The flowchart of methodology as can be seen on Figure 1.

\section{E. Research Flow Chart}

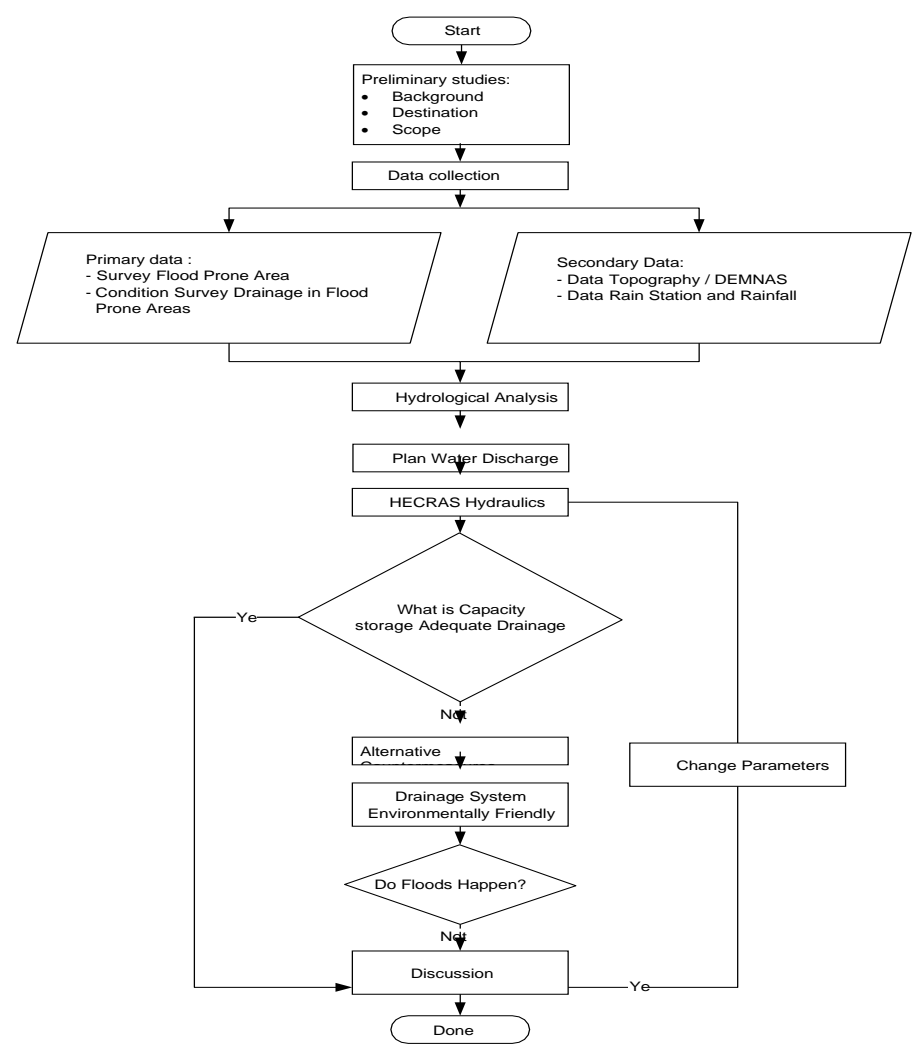

Figure 1. Flow Chart of Research and Methodology 


\section{Results and Discussion}

\section{A. Hydrological Analysis}

The rainfall data stations which affected on the study area are the Senre and Tamangapa Kassi stations. The recapitulation of the average rainfall data can be seen in Table 1 and Table 2.

Table 1. Maximum Rainfall of Tallo Sub-watershed

\begin{tabular}{|c|c|c|c|}
\hline \multirow{3}{*}{ Year } & \multicolumn{2}{|c|}{$\begin{array}{c}\text { Annual Maximum Daily } \\
\text { Rainfall (mm) }\end{array}$} & \multirow{3}{*}{ Total } \\
\hline & Tamangapa Kassi & Senre & \\
\hline & 0.3700 & 0.6300 & \\
\hline 1995 & 78.4331 & 49.7726 & 128.21 \\
\hline 1996 & 73.9935 & 89.4646 & 163.46 \\
\hline 1997 & 37.3667 & 42.8422 & 80.21 \\
\hline 1998 & 36.2568 & 41.5821 & 77.84 \\
\hline 1999 & 38.8466 & 68.0435 & 106.89 \\
\hline 2000 & 123.9392 & 121.5962 & 245.54 \\
\hline 2001 & 53.6453 & 77.4940 & 131.14 \\
\hline 2002 & 63.6344 & 115.2959 & 178.93 \\
\hline 2003 & 39.5865 & 86.9445 & 126.53 \\
\hline 2004 & 34.4070 & 78.7540 & 113.16 \\
\hline 2005 & 36.2568 & 69.3036 & 105.56 \\
\hline 2006 & 39.5865 & 190.8998 & 230.49 \\
\hline 2007 & 44.3961 & 141.7573 & 186.15 \\
\hline 2008 & 50.6856 & 119.7061 & 170.39 \\
\hline 2009 & 33.2971 & 113.4058 & 146.70 \\
\hline 2010 & 29.5974 & 77.4940 & 107.09 \\
\hline 2011 & 44.3961 & 56.7029 & 101.10 \\
\hline 2012 & 43.6562 & 74.3438 & 118.00 \\
\hline 2013 & 36.2568 & 127.8966 & 164.15 \\
\hline 2014 & 28.8575 & 72.4537 & 101.31 \\
\hline 2015 & 52.5354 & 106.4755 & 159.01 \\
\hline 2016 & 33.2971 & 71.8237 & 105.12 \\
\hline 2017 & 53.6453 & 100.8052 & 154.45 \\
\hline 2018 & 58.7014 & 121.5962 & 180.30 \\
\hline 2019 & 58.0436 & 149.3177 & 207.36 \\
\hline
\end{tabular}

Table 2. Maximum Rainfall of Mangalarang Sub-watershed

\begin{tabular}{|c|c|c|c|}
\hline \multirow{3}{*}{ Year } & \multicolumn{2}{|c|}{$\begin{array}{c}\text { Annual Maximum Daily } \\
\text { Rainfall }(\mathrm{mm})\end{array}$} & \multirow{3}{*}{ Total } \\
\hline & Tamangapa Kassi & Senre & \\
\hline & 0.0558 & 0.9442 & \\
\hline 1995 & 11.8356 & 74.5896 & 86.43 \\
\hline 1996 & 11.1657 & 134.0724 & 145.24 \\
\hline 1997 & 5.6387 & 64.2037 & 69.84 \\
\hline 1998 & 5.4712 & 62.3153 & 67.79 \\
\hline 1999 & 5.8620 & 101.9705 & 107.83 \\
\hline 2000 & 18.7025 & 182.2251 & 200.93 \\
\hline 2001 & 8.0951 & 116.1331 & 124.23 \\
\hline 2002 & 9.6025 & 172.7834 & 182.39 \\
\hline 2003 & 5.9736 & 130.2957 & 136.27 \\
\hline 2004 & 5.1920 & 118.0215 & 123.21 \\
\hline 2005 & 5.4712 & 103.8589 & 109.33 \\
\hline 2006 & 5.9736 & 286.0840 & 292.06 \\
\hline 2007 & 6.6994 & 212.4386 & 219.14 \\
\hline 2008 & 7.6485 & 179.3926 & 187.04 \\
\hline 2009 & 5.0246 & 169.9509 & 174.98 \\
\hline 2010 & 4.4663 & 116.1331 & 120.60 \\
\hline 2011 & 6.6994 & 84.9754 & 91.67 \\
\hline 2012 & 6.5878 & 111.4122 & 118.00 \\
\hline 2013 & 5.4712 & 191.6668 & 197.14 \\
\hline 2014 & 4.3546 & 108.5797 & 112.93 \\
\hline 2015 & 7.9276 & 159.5650 & 167.49 \\
\hline 2016 & 5.0246 & 107.6356 & 112.66 \\
\hline 2017 & 8.0951 & 151.0675 & 159.16 \\
\hline 2018 & 8.8581 & 182.2251 & 191.08 \\
\hline 2019 & 8.7588 & 223.7687 & 232.53 \\
\hline
\end{tabular}

Table 3. Tallo Hulu Sub-watershed Distribution Test Recapitulation

\begin{tabular}{|c|c|c|c|c|}
\hline \multirow{2}{*}{ No. } & Year & \multicolumn{2}{|c|}{ Distribution Method } & \multirow{2}{*}{ Information } \\
\cline { 3 - 4 } & Gumbel & $\begin{array}{c}\text { Log Person } \\
\text { III }\end{array}$ & \\
\hline 1 & $\begin{array}{c}\text { Smirnov } \\
\text { Kolmogorov }\end{array}$ & 0.1475 & 0.1282 & $\begin{array}{c}\text { Critical Value } \\
=0.27\end{array}$ \\
\hline 2 & Chi Square & 6.44 & 6.44 & $\begin{array}{c}\text { Critical Value } \\
=7.815\end{array}$ \\
\hline
\end{tabular}


Table 4. Mangalarang Sub-watershed Distribution Test Recapitulation

\begin{tabular}{|c|c|c|c|c|}
\hline \multirow{2}{*}{ No. } & \multirow{2}{*}{ Test } & \multicolumn{2}{|c|}{ Distribution Method } & \multirow{2}{*}{ Information } \\
\cline { 3 - 4 } & Gumbel & $\begin{array}{c}\text { Log Pearson } \\
\text { III }\end{array}$ & \\
\hline 1 & $\begin{array}{c}\text { Smirnov } \\
\text { Kolmogorov }\end{array}$ & 0.1465 & 0.1282 & $\begin{array}{c}\text { Critical Value } \\
=0.27\end{array}$ \\
\hline 2 & Chi Square & 1.64 & 12.68 & $\begin{array}{c}\text { Critical Value } \\
=7.815\end{array}$ \\
\hline
\end{tabular}

Tables 3 and 4 show that the rainfall plans on sub watershed upstream Tallo was calculated using distribution Log Pearson III and the subzone Mangalarang using Gumbel distribution. The runoff coefficient $C$ in the Upper Tallo sub-watershed and the Mangalarang sub-watershed is 0.7. The value of effective rainfall for each sub-watershed can be seen in table 5 and table 6 .

Table 5. The effective rainfall of Tallo Subwatershed

\begin{tabular}{|c|c|c|c|c|c|c|c|c|}
\hline $\mathrm{t}$ & $\mathrm{C}$ & 5 & 10 & 20 & 25 & 50 & 100 & 1000 \\
\hline 1 & 0.7 & 68.48 & 78.66 & 86.87 & 91.29 & 100.55 & 109.74 & 140.54 \\
\hline 2 & 0.7 & 17.80 & 20.45 & 22.58 & 23.73 & 26.14 & 28.52 & 36.53 \\
\hline 3 & 0.7 & 12.49 & 14.34 & 15.84 & 16.64 & 18.33 & 20.01 & 25.62 \\
\hline 4 & 0.7 & 9.94 & 11.42 & 12.61 & 13.25 & 14.60 & 15.93 & 20.40 \\
\hline 5 & 0.7 & 8.39 & 9.64 & 10.65 & 11.19 & 12.33 & 13.45 & 17.23 \\
\hline 6 & 0.7 & 7.34 & 8.43 & 9.31 & 9.78 & 10.77 & 11.76 & 15.06 \\
\hline
\end{tabular}

Table 6. The Effective Rainfall of Mangalarang Subwatershed

\begin{tabular}{|c|c|c|c|c|c|c|c|c|}
\hline $\begin{array}{c}\mathrm{t} \\
\text { (hour) }\end{array}$ & $\mathrm{C}$ & 5 & 10 & 20 & 25 & 50 & 100 & 1000 \\
\hline 1 & 0.7 & 76.21 & 90.71 & 104.63 & 109.04 & 122.64 & 136.14 & 180.74 \\
\hline 2 & 0.7 & 19.81 & 23.58 & 27.20 & 28.34 & 31.88 & 35.39 & 46.98 \\
\hline 3 & 0.7 & 13.89 & 16.54 & 19.08 & 19.88 & 22.36 & 24.82 & 32.95 \\
\hline 4 & 0.7 & 11.06 & 13.17 & 15.19 & 15.83 & 17.80 & 19.76 & 26.23 \\
\hline 5 & 0.7 & 9.34 & 11.12 & 12.82 & 13.37 & 15.03 & 16.69 & 22.15 \\
\hline 6 & 0.7 & 8.17 & 9.72 & 11.21 & 11.68 & 13.14 & 14.59 & 19.37 \\
\hline
\end{tabular}

The amount of the discharge design is determined based on the amount of planned rainfall and the characteristics of the watershed. The design flood discharge for fhe upper Tallo Sub-watershed is:
Watershed area (A)
$=70.85 \mathrm{~km}^{2}$
Main River Length (L)$$
=18.53 \mathrm{~km}
$$

$\begin{array}{ll}\text { Coefficient }(\alpha) & =2 \\ \text { Delay Time }(\mathrm{tg}) & =1.47 \text { hours } \\ \text { Peak Time }(\mathrm{Tp}) & =2.36 \text { hours } \\ \text { Rain Duration }(\mathrm{Tr}) & =1.11 \text { hours } \\ \text { Time When Discharge } 0.3 \text { time } & \text { peak discharge } \\ \left(\mathrm{t}_{0.3)}\right) & =2.95 \text { hours } \\ \text { Peak Flood Discharge } \mathrm{Q}_{\mathrm{p}} & =5.38 \mathrm{~m}^{3} / \mathrm{s} \\ \mathrm{t}_{\mathrm{p}}+\mathrm{t}_{0.3} & =5.31 \text { hours } \\ \mathrm{t}_{\mathrm{p}}+\mathrm{t}_{0.3}+1.5+\mathrm{t}_{0.3} & =9.73 \text { hours } \\ 0.5 \mathrm{t}_{0.3} & =1.47 \text { hours } \\ 1.5 \mathrm{t}_{0.3} & =4.42 \text { hours } \\ 2 \mathrm{t}_{0.3} & =5.90 \text { hours }\end{array}$

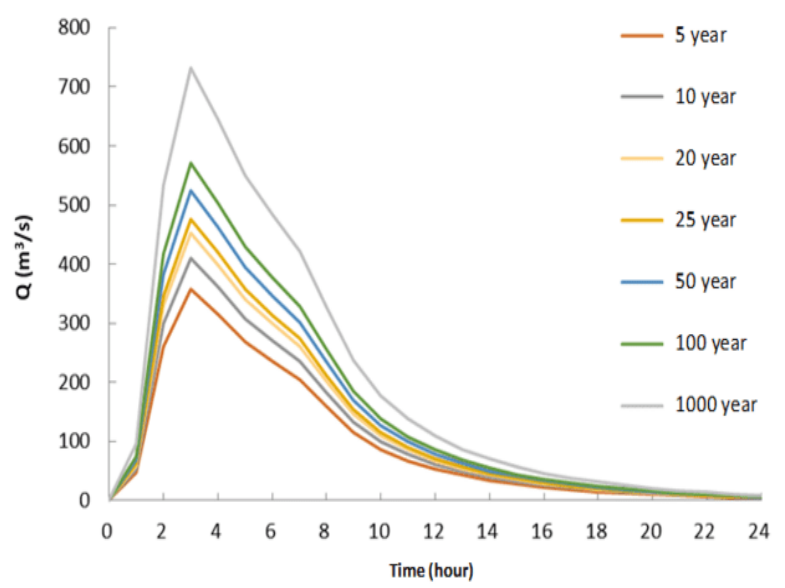

Figure 2. Flood Hydrograph of Upper Tallo Sub-watershed using Nakayasu Method

The design flood discharge for the Mangalarang subwatershed is:
Watershed area (A)
Main River Length (L)
Coefficient $(\alpha)$
Delay Time $(\mathrm{tg})$
$=168.29 \mathrm{~m}^{2}$
$=49.25 \mathrm{~km}$
$=2$
Peak Time $(\mathrm{Tp})$
$=3.26$ hours
$=5.21$ hours
Rain Duration (Tr)
$=2.44$ hours

Time When Discharge is equal to 0.3 times peak discharge ( $t 0.3)$

$=6.51$ hours

Peak Flood Discharge $Q_{p}$

$=5.79 \mathrm{~m} 3 / \mathrm{s}$

$\mathrm{t}_{\mathrm{p}}+\mathrm{t}_{0.3}$

$=11.72$ hours

$\mathrm{t}_{\mathrm{p}}+\mathrm{t}_{0.3}+1.5+\mathrm{t}_{0.3}$

$=21.49$ hours

$0.5 \mathrm{t}_{0.3} \quad=3.26$ hours

$1.5 \mathrm{t}_{0.3} \quad=9.77$ hours

$2 \mathrm{t} 0.3$

$=13.03$ hours 


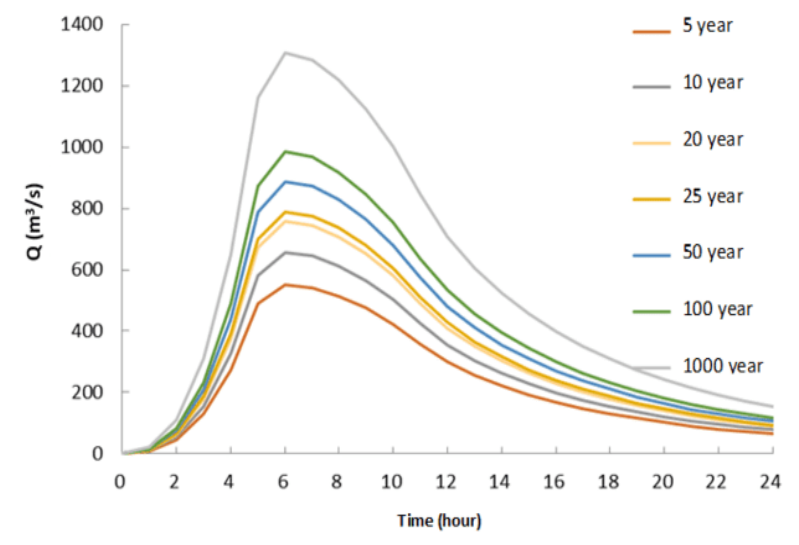

Figure 3. Mangalarang Sub-watershed Flood Hydrograph with Nakayasu Method

\section{B. Performance of the Existing Condition of the Tallo . River}

Hydraulics analysis uses a 2D non-permanent flow model with the help of the HEC-RAS application. The Tallo River is located in an urban area where the design flood discharge requirements used are $\mathrm{Q}_{20}-\mathrm{Q}_{50}$, so that in this study the flood simulation uses a flood with a return period of 50 years. The following is a map of the simulation results of the Tallo River flood, as seen in fig. 4

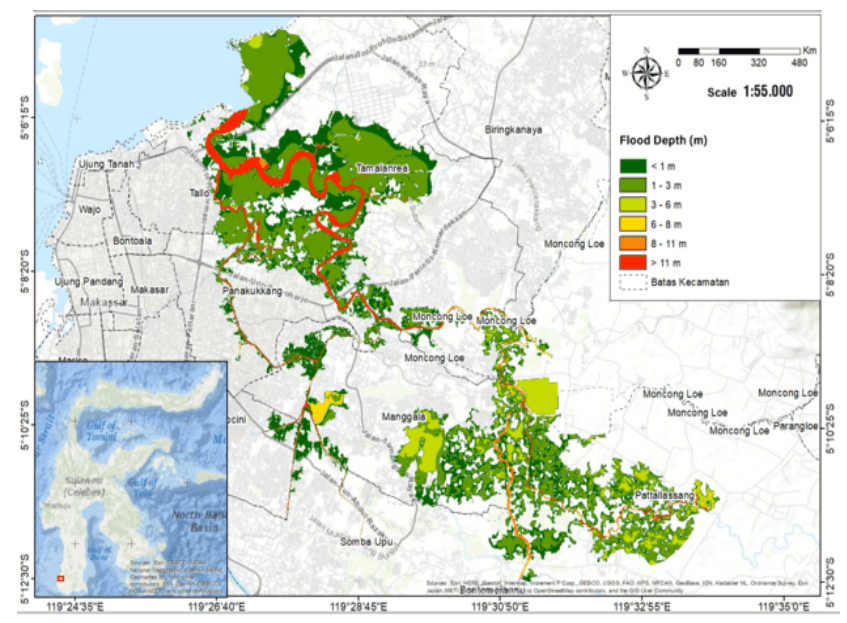

Figure 4. Tallo River Flood Area Map

Based on the results of mapping the flood-prone areas of Makassar City, from the simulation results above, it can be seen the performance of the existing conditions of the Tallo River. The flood area which affected based on sub-districts in Makassar can be seen in the Table 7.
Tabel 7. The Affected Area based on subdictricts in Makassar

\begin{tabular}{|c|l|c|}
\hline No. & \multicolumn{1}{|c|}{ Sub-Districts } & $\begin{array}{c}\text { Total Area }\left(\mathrm{km}^{2}\right) \\
\left(\mathrm{km}^{2}\right)\end{array}$ \\
\hline 1 & Mangala & 6.48 \\
\hline 2 & Rappocini & 0.31 \\
\hline 3 & Panakukang & 4.24 \\
\hline 4 & Tallo & 3.37 \\
\hline 5 & Tamalanrea & 11.59 \\
\hline 6 & Biringkanaya & 0.01 \\
\hline \multicolumn{2}{|r|}{ Total } & 26.00 \\
\hline
\end{tabular}

\section{Environmentally Friendly Drainage System to Overcome Makassar City Flood}

By mel That s results urvey field and the simulation result of flooding can be concluded that the tide is very influential on benjir occurring downstream Tallo River. Thus, it is necessary to revitalize the Tallo River by means of ecodrain, namely a retention pond. $\mathrm{K}$ olam ret ensi expected to reduce the flood water to slow the tide with a meeting between the flood discharge of the river from upstream. Figure 5 shows the results of the flood simulation before the retention pond.

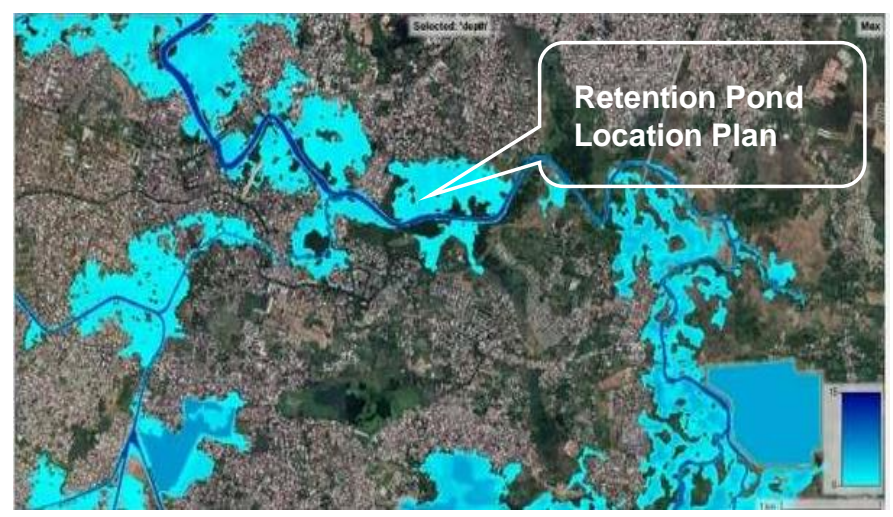

Figure 5. The location of Retention Pond Plan

The planning for retention pond in the downstream of Tallo River can be seen in Figure 6 which is in District Tamalanrea at coordinates $5^{\circ} 10^{\prime} 3,13$ " latitude and $119^{\circ} 31$ '10,93" BT, plan dimensions as follows:

$\begin{array}{ll}\text { Retention Pool Area } & : 353783.47 \mathrm{~m}^{2} \\ \text { Pool Base Elevation } & :-7.00 \mathrm{~m} \\ \text { Spillway Elevation } & :+0.00 \mathrm{~m} \\ \text { Spillway Length } & : 58.5 \mathrm{~m} \\ \text { Pool Embankment Height } & :+8.00 \\ \text { River Embankment Height } & :+8.00 \\ \text { Normal Storage Volume } & : 2.48 \text { million } \mathrm{m}^{3}\end{array}$




\section{Maximum Storage Volume $\quad: 5.31$ million $\mathrm{m}^{3}$}

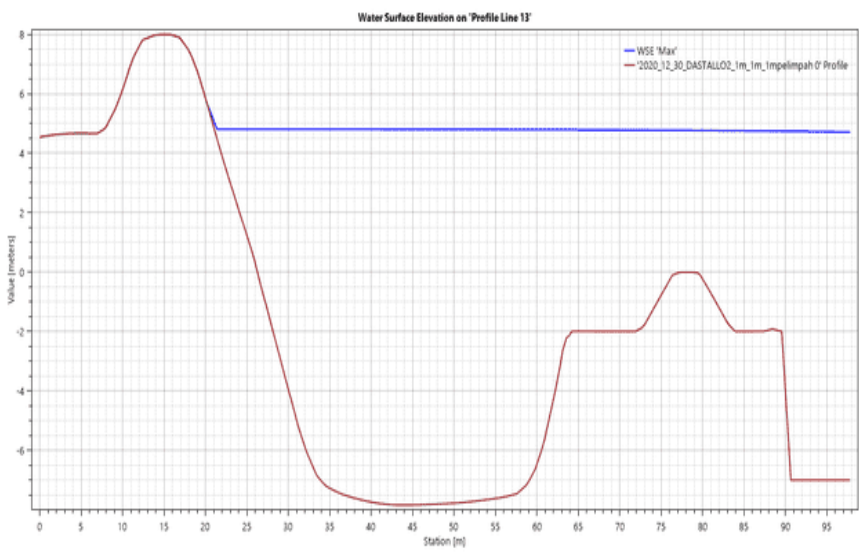

Figure 6. Cross Section of the Retention Pond Spillway Elevation Plan Retensi

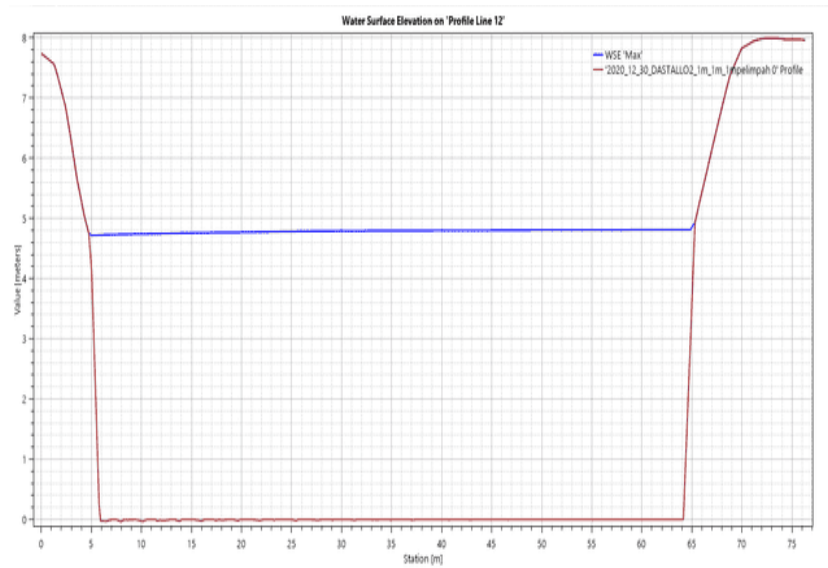

Gambar 7. Longitudinal Piece of Retention Pond Spillway

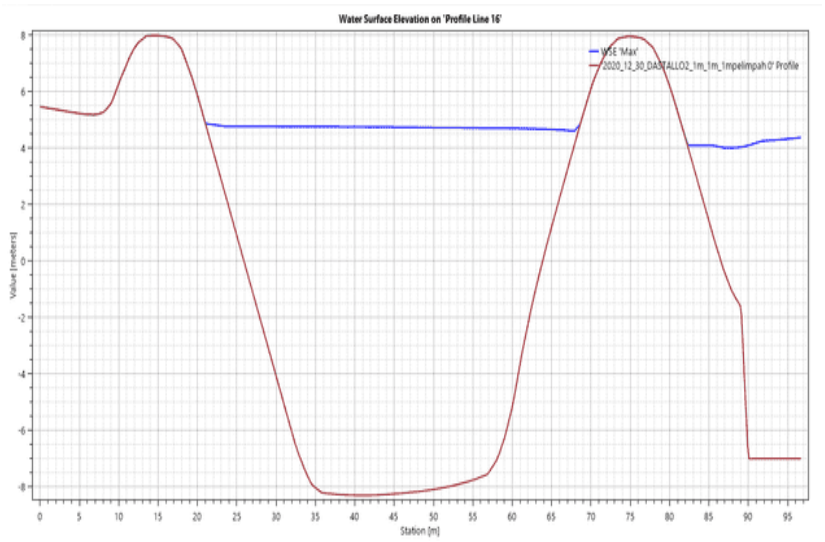

Figure 8. Cross Section of Pond Embankment and River Embankment
Figure 9 shows the condition of the simulated flooded area after the downstream retention pond

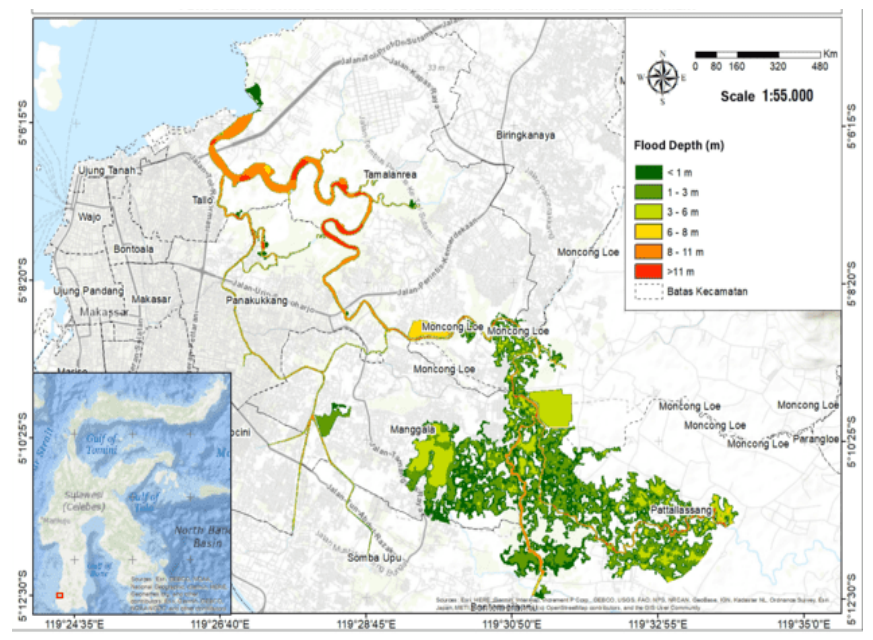

Figure 9. Map of the Areas Affected by the Flood of the Tallo River after the Downstream Retention Pond

Based on Figures 4 and 9, it can be seen that the difference in flood-affected areas before and after the downstream retention pond is established, for more details, see the following table 8 .

Table 8. Area of Tallo River Flood Affected Before and After the Downstream Retention Pond

\begin{tabular}{|c|c|c|c|c|}
\hline No. & Districts & $\begin{array}{c}\text { Area of Flood } \\
\text { Affected Before } \\
\text { Downstream } \\
\text { Retention Pond } \\
\left(\mathrm{km}^{2}\right)\end{array}$ & $\begin{array}{c}\text { Area of Flood } \\
\text { Affected After } \\
\text { Downstream } \\
\text { Retention Pond } \\
\left(\mathrm{km}^{2}\right)\end{array}$ & $\begin{array}{c}\text { Difference } \\
\left(\mathrm{km}^{2}\right)\end{array}$ \\
\hline 1 & Mangala & 6.48 & 4.94 & 1.54 \\
\hline 2 & Rappocini & 0.31 & 0.05 & 0.26 \\
\hline 3 & Panakukang & 4.24 & 0.61 & 3.63 \\
\hline 4 & Tallo & 3.37 & 0.92 & 2.45 \\
\hline 5 & Tamalanrea & 11.59 & 1.77 & 9.82 \\
\hline 6 & Biringkanaya & 0.01 & 0.01 & 0.00 \\
\hline & Total & 26.00 & 8.30 & 17.70 \\
\hline
\end{tabular}

Based on the table above, the total area of inundation that can be reduced from the presence of a downstream retention pond is $17.70 \mathrm{~km}^{2}$

\section{Conclusion}

Based on the results of the research conducted, the following conclusions can be drawn:

1. Dischage flooding upstream into the river Tallo is divided into two sub-watershed is subzone subzone Tallo Hulu and flood discharge 
Mangalarang with $\mathrm{Q}_{50}=523.76 \mathrm{~m}^{3} / \mathrm{sec}$ and $\mathrm{Q}_{50}$ $=886.82 \mathrm{~m}^{3} / \mathrm{sec}$.

2. The flood of the Tallo River caused 6 subdistricts to be affected by flooding, namely Manggala $\left(6.48 \mathrm{~km}^{2}\right)$, Rappocini $\left(0.31 \mathrm{~km}^{2}\right)$, Panakukang $\left(4.24 \mathrm{~km}^{2}\right)$, Tallo $\left(3.37 \mathrm{~km}^{2}\right)$, Tamalanrea $\left(11.59 \mathrm{~km}^{2}\right)$ and Biringkanaya $\left(0.01 \mathrm{~km}^{2}\right)$. So the total area affected is $26 \mathrm{~km}^{2}$

3. The solution to cope with the flood Tallo River drainage system that is environmentally sound development plan retention ponds downstream with a total catchment normal volume of 2.48 million $\mathrm{m}^{3}$ and a maximum capacity of 5.31 million $\mathrm{m}^{3}$ can reduce about $17.7 \mathrm{~km}^{2}$ area affected by flood

\section{Acknowledgement}

We express our deepest gratitude to the Makassar City Government for providing recommendations to conduct research on the revitalization of the Makassar Urban drainage system.

\section{References}

[1] Herlambang, Widhita Satya."Evaluasi Kinerja Sistem Drainase di Wilayah Jombang", (Evaluation of Drainage System Performance in the Jombang Region), Skripsi. Malang, Institut Teknologi Nasional Malang. 2015.

[2] Dwijaya, Alber."Evaluasi Drainase Perkotaan Dengan Metode HECRAS di Kota Nanga Bulik Lamandu Propinsi Kalimantan Tengah", (Evaluation of Urban Drainage Using the HECRAS Method in Nanga Bulik Lamandu City, Central Kalimantan Province), Jurnal Rekayasa Sipil. Vol. 2, No.2, Agustus 2014, Hlm $104-115$.
[3] Mahardy, Andi Ikmal."Analisis dan Pemetaan Daerah Rawan Banjir di Kota Makassar Berbasis Spatial", (Analysis and Mapping of Flood Prone Areas in Makassar City Based on Spatial). Skripsi. Makassar Universitas Hasanuddin, 2014.

[4] Badan Nasional Penanggulangan Bencana. "Daftar Informasi Bencan Indonesia (DIBI)", (List of Indonesian Disaster Information). (Online), (https:dibi.bnpb.go.id), 2014. Acessed on 26 February 2021.

[5] Zubair, A., Hatta, M.P., Rudyanto . "Identifikasi Zona Genangan Banjir Kota Makassar Berbasis SIG", (Identification of the Makassar City Flood Inundation Zone Based on GIS), (Online), (https://core.ac.uk/download/pdf/77621993.pdf). 2014.

[6] Muhammad Fathien Azmy, Yashinta Sutopo, Ranthy Mantong, "Penataan Drainase dengan Penekanan Evaluasi Zona Drainase di Kecamatan Ujung Pandang, Makassar", (Drainage Management with Emphasis on Evaluation of Drainage Zones in Ujung Pandang District, Makassar), Prosiding Seminar Ilmiah Nasional Sains dan Teknologi ke-4, Vol 4. November, 2018.

[7] Reza Eka Putri Damayanti, Kuswanto Nurhadi, Isti Andini, "Pengaruh Revitalisasi Sungai Terhadap Kinerja Sistem Drainase Kali Pepe Hilir Kota Surakarta", (The Effect of River Revitalization on the Performance of the Pepe Hilir River Drainage System in Surakarta). Jurnal Region, Vol. 6, No. 2, July 2015.

[8] Maryono,"Eko-Hidrolik Pengelolaan Sungai Ramah Lingkungan", (Eco-Hydraulic Eco-Friendly River Management). Gajah Mada University Press. Yogyakarta, August 2007.

[9] Roby Hambali,"Revitalisasi Fungsi Sistem Drainase Berbasis Pemberdayaan Masyarakat dalam Rangka Pengurangan Resiko”, (Revitalizing the Function of the Drainage System Based on Community Empowerment in the Context of Reducing Risk), Jurnal Pengabdian Kepada Masyarakat Universitas Bangka Belitung, 2015.

[10] R. Karamma and M.S.Pallu, "Comparison of Model Hydrograph Synthetic Units (HSS) with the Model of Hydrograph Observations on DAS Jeneberang Gowa Regency, Indonesia, International Journal of Innovative Science and Research Technology (IJISRT), Vol. 3, Issue 2, February 2018. 